\title{
Effect of a short-term HAART on SIV load in macaque tissues is dependent on time of initiation and antiviral diffusion
}

Olivier Bourry ${ }^{1,4,5}$, Abdelkrim Mannioui $^{1,4}$, Pierre Sellier $^{1,2,4}$, Camille Roucairol ${ }^{3}$, Lucie Durand-Gasselin ${ }^{3}$, Nathalie Dereuddre-Bosquet ${ }^{1,4}$, Henri Benech ${ }^{3}$, Pierre Roques ${ }^{1,4}$, Roger Le Grand ${ }^{1,4^{*}}$

\begin{abstract}
Background: HIV reservoirs are rapidly established after infection, and the effect of HAART initiated very early during acute infection on HIV reservoirs remains poorly documented, particularly in tissue known to actively replicate the virus. In this context, we used the model of experimental infection of macaques with pathogenic SIV to assess in different tissues: (i) the effect of a short term HAART initiated at different stages during acute infection on viral dissemination and replication, and (ii) the local concentration of antiviral drugs.

Results: Here, we show that early treatment with AZT/3TC/IDV initiated either within 4 hours after intravenous infection of macaques with SIVmac251 (as a post exposure prophylaxis) or before viremia peak (7 days postinfection [pi]), had a strong impact on SIV production and dissemination in all tissues but did not prevent infection. When treatment was initiated after the viremia peak (14 days pi) or during early chronic infection (150 days pi), significant viral replication persists in the peripheral lymph nodes and the spleen of treated macaques despite a strong effect of treatment on viremia and gut associated lymphoid tissues. In these animals, the level of virus persistence in tissues was inversely correlated with local concentrations of 3TC: high concentrations of 3TC were measured in the gut whereas low concentrations were observed in the secondary lymphoid tissues. IDV, like 3TC, showed much higher concentration in the colon than in the spleen. AZT concentration was below the quantification threshold in all tissues studied.
\end{abstract}

Conclusions: Our results suggest that limited antiviral drug diffusion in secondary lymphoid tissues may allow persistent viral replication in these tissues and could represent an obstacle to HIV prevention and eradication.

\section{Background}

The acute phase of human or simian immunodeficiency virus (HIV/SIV) infections is decisive as it is characterized by a quick and strong decrease of T CD4+ memory cells, particularly in the gut associated lymphoid tissue (GALT), and a rapid spread of the virus in all lymphoid tissues $[1,2]$. In a recent study, we have shown that during acute SIV infection of macaques, the kinetics of viral dissemination and replication differ between the different lymphoid tissues. Following the peak of viremia, viral DNA and RNA persist at high levels in the secondary lymphoid tissues (spleen and lymph nodes), whereas

\footnotetext{
* Correspondence: roger.legrand@cea.fr

${ }^{1}$ CEA, Division of Immuno-Virology, DSV/iMETI, Fontenay-aux-Roses, France Full list of author information is available at the end of the article
}

they rapidly decrease in the blood and the gut [3]. Therefore, this study reinforces the need to explore not only the blood, but also the different lymphoid tissues when assessing strategies aimed at reducing SIV/HIV reservoirs.

HAART initiated very early during infection could prevent the loss of $\mathrm{CD} 4+\mathrm{T}$ cells from the gut and may delay the onset of the disease [4]. While HIV reservoirs are also set up during acute infection, few studies have focused on the effect of early HAART on tissue viral replication and reservoirs.

Because of the difficulty to obtain tissue samples from HIV infected patients, the macaque models are particularly useful for the exploration of viral dissemination and replication in the different body compartments, especially during the early phases of infection [5]. In the

\footnotetext{
Fullist of author information is avallable at the end of the article
}

(c) 2010 Bourry et al; licensee BioMed Central Ltd. This is an Open Access article distributed under the terms of the Creative Commons Attribution License (http://creativecommons.org/licenses/by/2.0), which permits unrestricted use, distribution, and reproduction in any medium, provided the original work is properly cited. 
present study, we explored the effect of a short term HAART initiated at different stages during SIV acute infection on the viral burden in the main lymphoid tissues, including the gut. Different quantitative approaches were used, including total SIV-DNA to evaluate viral dissemination and SIV-RNA to assess viral replication and production. As 2LTR SIV-DNA circles have been suggested to accumulate in recently infected target cells [6], we also explored the value of their quantification as an additional method to assess the impact of treatment on viral dissemination.

We show that the Zidovudine (AZT)/Lamivudine (3TC) and Indinavir (IDV) combination could efficiently reduce viral dissemination and replication in all tissues when treatment was initiated before the peak of viremia. Surprisingly, when the same treatment was started after the viremia peak, the effect of treatment was stronger in the gut than in the secondary lymphoid tissues; this is likely due to the very heterogeneous tissue diffusion of several of the antiretroviral drugs.

\section{Results}

A short term HAART initiated during early chronic SIV infection reduces plasma viral load but has a weak effect on secondary lymphoid tissues

In a first step, to validate our HAART treatment in the SIV macaque model, we assessed the effect of the AZT/ 3TC/IDV combination in chronically infected animals. Six macaques infected with SIVmac251 were treated with AZT/3TC/IDV twice a day after viral set point (from day $150 \mathrm{pi}$ ). To determine the kinetics of viral load decrease in different tissues, three of these animals were killed at day 14 (chronic HAART 14d) and the other three at day 28 (chronic HAART 28d) after the onset of treatment. Three untreated animals at the same stage of infection were used as controls (chronic untreated). Among the HAART treated animals, one (\#20929) had undetectable PVL at the initiation of therapy (day 0), but was nevertheless included in the analysis since cell-associated viral load (CVL) in PBMC evolved within the same range of the other treated macaques.

We confirmed that in macaques chronically infected with SIV, four weeks of HAART result in a decrease of plasma viral load (PVL) similar to that observed in HIVinfected patients receiving similar treatment [7]. As early as day 14 of treatment, the PVL was reduced by $1.7 \times \log 10$ in geometric (G) mean, and three of these animals had decreased PVL below detection threshold (60 vRNA copies/ml) (Figure 1a). After 28 days of therapy, only one macaque (\#20828) had persistent viremia which was slightly reduced when compared to day 0 $(-0.9 \times \log 10)$.
We then explored viral dissemination and replication in PBMC, spleen, lymph nodes (LN) and the gut to assess whether the decrease in plasma viral load reflects similar dynamics in the other tissues. As previously observed in patients infected with HIV, SIV-DNA in PBMC was only slightly reduced by treatment, with $G$ mean reductions of $0.4 \times \log 10$ and $1.1 \times \log 10$ after 14 and 28 days of treatment, respectively (Figure $1 \mathrm{~b}$ ). Interestingly, the level of SIV-DNA was not significantly reduced in the lymph nodes and spleen of treated animals (Figure 1c). We surmised that the limited effect of treatment in these tissues could be explained by the limited diffusion of antivirals in these compartments and/or the inefficiency of the drug on long-lived infected cells. In contrast, treatment had a strong effect in the digestive tract with a $G$ mean reduction of $1.8 \times \log 10$ in colon ( $p=0.049$ at day 28 ). This tissue has predominantly short-lived CD4+ T cells facilitating the effect of HAART [8]. Also, the antivirals may diffuse better in these tissues.

We then measured levels of 2LTR SIV-DNA, as a marker of recently infected cells as previously suggested [6]. In untreated animals, we detected 2LTR SIV-DNA in all the tissues studied. In macaques treated with HAART for 28 days, levels of 2LTR SIV-DNA were significantly reduced $(p=0.04)$ in the ileum when compared to animals receiving only 14 days of HAART. On the contrary, the antiviral treatment had no effect on the 2LTR SIV-DNA levels in the LN and the spleen. Although the value of 2LTR viral DNA circles is still controversial, our result suggests that treatment probably affects efficiently the tissues with a predominance of new infections (Figure 1d).

Finally, we measured SIV-RNA levels to assess the production of SIV. Under treatment there is a significant $(p=0.03)$ decrease of SIV-RNA levels if we consider all compartments; but due to the limited number of animals in each group, the effect was not significant for each tissue separately. The strongest effect was observed in the gut, with a $\mathrm{G}$ mean decrease of $2.4 \times \log 10$ (Figure 1e), confirming the results observed for viral DNA in the GALT. The effect of treatment on SIV-RNA levels was more limited in the $\mathrm{LN}$ and spleen ( $G$ mean decrease of tissue viral load: $1.8 \times \log 10)$.

\section{AZT/3TC/IDV treatment initiated before viremia peak results in partial control of viral dissemination and replication in tissues}

When started during early chronic infection, a short term HAART showed a limited and not significant effect in LN and spleen. We then evaluated the effect of this treatment initiated at earlier stages hypothesizing that we might expect a better efficacy of HAART since viral reservoirs are probably not yet fully established. 


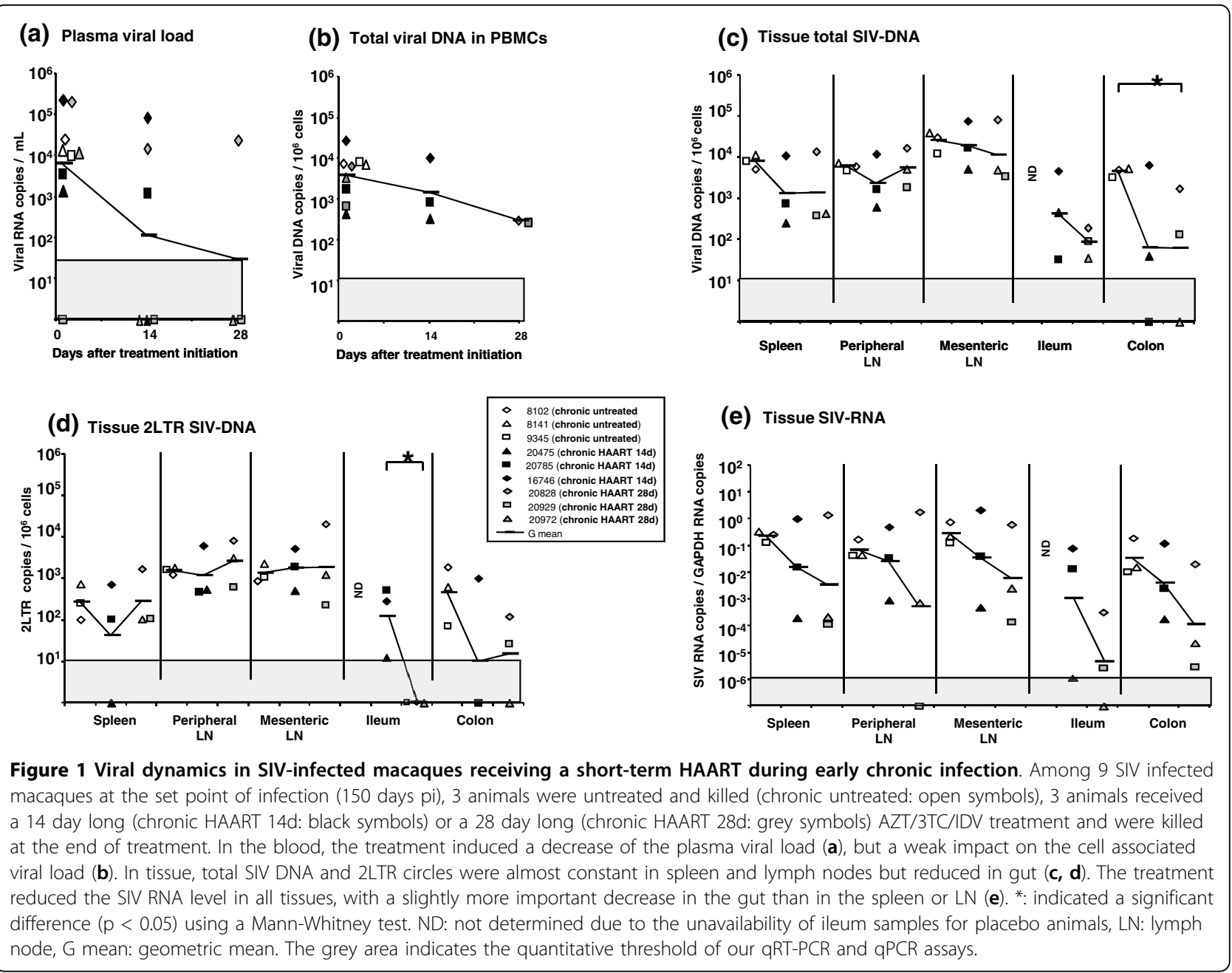

In a first experiment, two groups of four SIVinfected animals received AZT/3TC/IDV treatment or a placebo starting $4 \mathrm{~h}$ after intravenous inoculation of SIV. Animals were killed at day $14 \mathrm{pi}$, when viral replication and dissemination were expected to be maximal in placebo treated macaques (Figure 2a-e). Confirming our previously published observations [9], although early treatment could not prevent infection after intravenous transmission, at day $14 \mathrm{pi}$, PVL and CVL in HAART treated animals remained almost undetectable (Figure 2a-b). Although levels of viral RNA and DNA were close to the quantification threshold, virus remained detectable in spleen and mesenteric lymph nodes, confirming that residual SIV replication and dissemination persisted despite HAART was initiated very early (4h) after intravenous inoculation of SIV.

In a second experiment, two groups of four SIVinfected animals received AZT/3TC/IDV treatment or a placebo between 7 and 21 days post-infection and were killed at 21 days pi. In these animals, the effect of antiretroviral treatment was intermediate between what was observed in macaques treated as early as $4 \mathrm{~h}$ pi and macaques treated during early chronic infection. Thus, the PVL at day 21 pi was significantly lower in HAART treated animals than in placebo treated macaques $(-2 \times$ $\log 10, p=0.02$ ), but no significant effect was found for CVL (Figure 3a and 3b). (In the placebo group, animal \#14275 which displayed a controller profile was excluded from statistical analysis). In almost all tissues, a small but statistically significant decrease was observed for SIV-DNA ( $\mathrm{p}=0.03$ for spleen, peripheral LN, mesenteric LN and colon) (Figure 3c). The treatment also induced a significant decrease of 2LTR SIV DNA in the spleen, the peripheral $\mathrm{LN}$, and the colon $(\mathrm{p}=0.03$ for each tissue) (Figure 3d); while for SIV-RNA levels the decrease was significant $(\mathrm{p}=0.03)$ only in peripheral LN (Figure 3e). 
(a) Plasma viral load

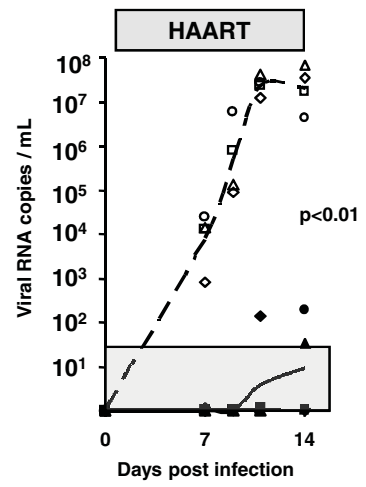

(d) Tissue 2LTR SIV-DNA

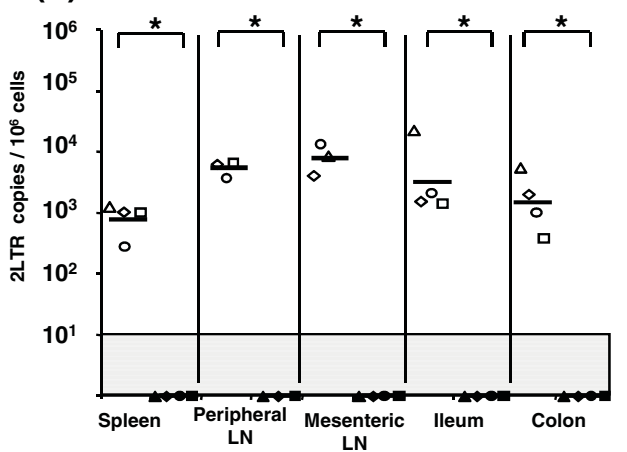

(b) Total viral DNA in PBMCs
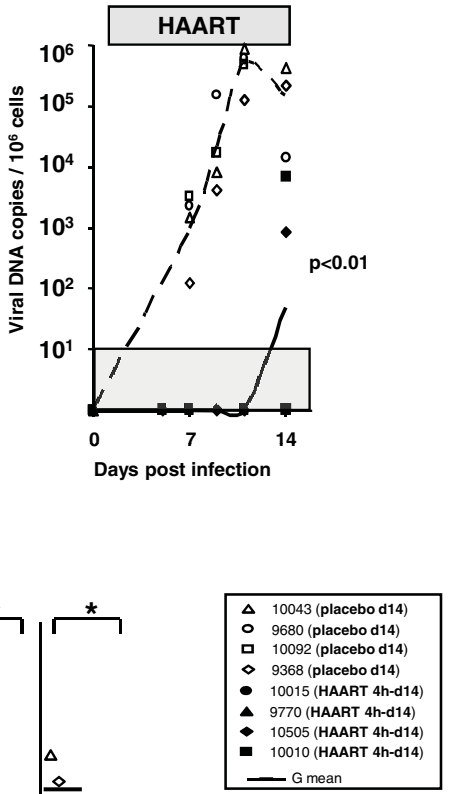

Figure 2 Viral dynamics in SIV-infected macaques receiving a short-term post exposure HAART. Four hours after SIV intravenous inoculation, 2 groups of 4 macaques received either the AZT/3TC/IDV combination (HAART 4h-d14) or a placebo (placebo d14), then were killed at the end of treatment (14 days pi). After intravenous infection, post exposure HAART controlled the plasma (a) and the cell associated viral load (b). In tissues collected 14 days after inoculation the viral dissemination (c) and replication (d, e) were almost undetectable in HAART 4hd14 animals (black symbols), whereas placebo d14 animals demonstrated extensive viral propagation (c) and replication (d,e) (open symbols). * indicated a significant difference $(p<0.05)$ using a Mann-Whitney test. LN: lymph node, G mean: geometric mean. The grey area indicates the quantitative threshold of our qRT-PCR and qPCR assays. (c) Tissue total SIV-DNA

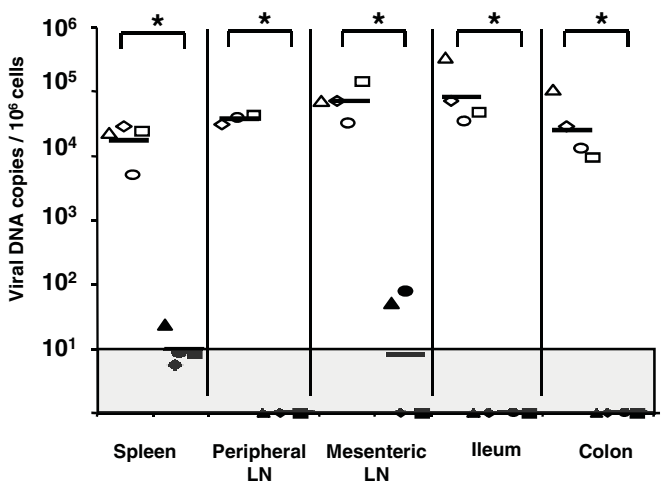

(e) Tissue SIV-RNA

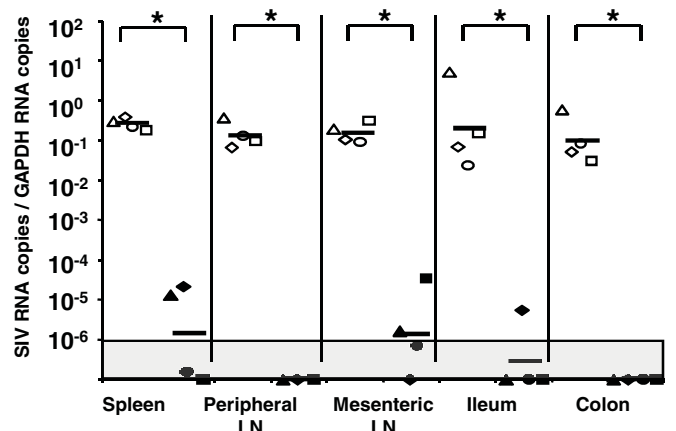

LN LN
Initiation of AZT/3TC/IDV therapy after the viremia peak results in limited and tissue-dependent effects on viral replication and dissemination

We then addressed the issue whether similar effects could be observed after maximal viral dissemination, at a time where viral reservoirs are expected to be fully established. The same treatment was therefore initiated (day 14 pi) just after viremia peak in a group of five macaques. PVL, CVL, total SIV-DNA, 2LTR SIV-DNA and SIV-RNA levels were determined 14 days later (day $28 \mathrm{pi}$ ) in different tissues and compared to levels of three placebo animals also euthanized at day 28 pi.

In HAART treated animals, the effect of treatment was limited. Plasma viral load was significantly lower than in placebo macaques $(p=0.02)$ (Figure $4 a)$. However, we did not observe any significant effect on CVL, total SIV-DNA, 2LTR or SIV-RNA levels, in the spleen or peripheral lymph nodes (Figure $4 \mathrm{~b}-\mathrm{e}$ ). By contrast, the three viral markers were reduced in the digestive 
(a) Plasma viral load

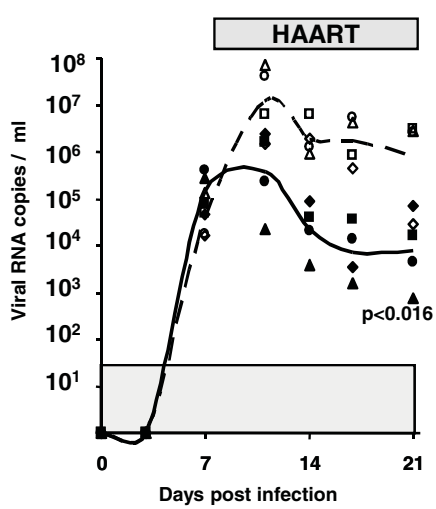

(b) Total viral DNA in PBMCs

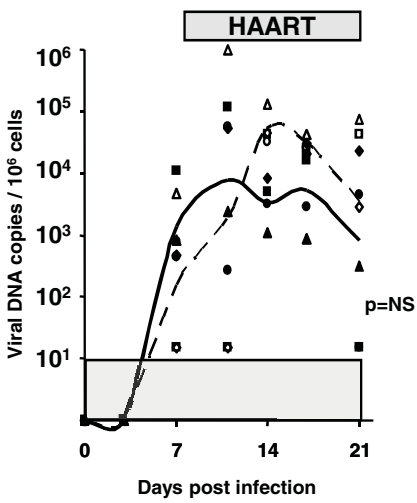

(c) Tissue total SIV-DNA

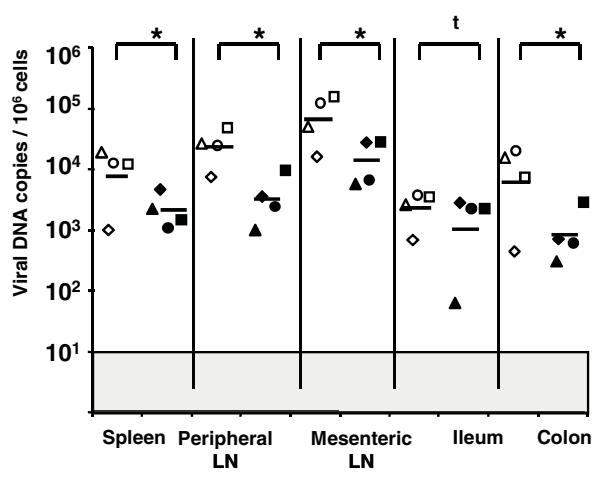

(e) Tissue SIV-RNA

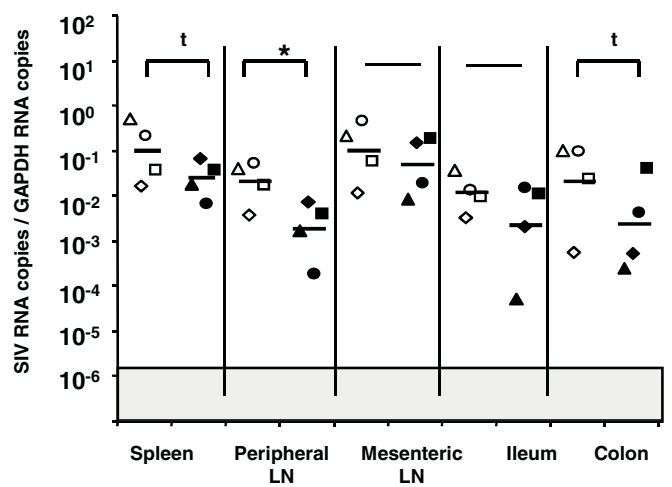

(d) Tissue 2LTR SIV-DNA

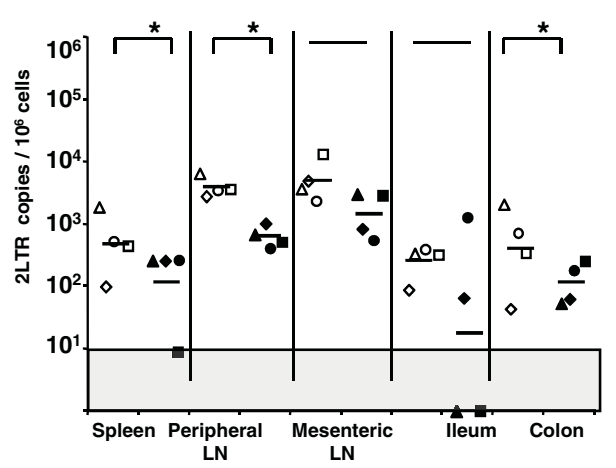

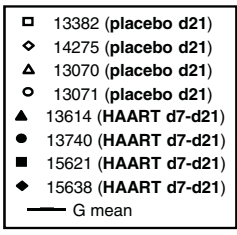

a 13382 (placebo d21) $\Delta \quad 13070$ (placebo d21) - 13071 (placebo d21) - 13740 (HAART d7-d21) 15638 (HAART d7-d21) - $\mathrm{G}$ mean

Figure 3 Viral dynamics in SIV-infected macaques receiving a short-term HAART before the viremia peak. Seven days after SIV infection, 4 macaques received either a placebo (placebo d21: open symbol) or the AZT/3TC/IDV combination (HAART d7-d21: black symbol) for 14 days and were killed at the end of treatment (21 days pi). Initiation of HAART 7 days after SIV infection conducts to a significant decrease of PVL (a) but non-significant reduction of CVL (b). Viral dissemination is also slightly (but significantly) impacted in almost all tissues (c), whereas viral replication is only reduced in the spleen, peripheral LN and colon (d, e). Due to its controller profile, placebo animal \#14275 was excluded from statistical analysis. *: indicated a significant difference $(p<0.05)$ and $t$ a trend $(0.05<p<0.06)$ using a Mann-Whitney test. LN: lymph node, G mean: geometric mean. The grey area indicates the quantitative threshold of our qRT-PCR and qPCR assays.

treated with HAART just after viremia peak were mainly $\mathrm{T}$ cells and not macrophages as they generally express CD3 (Figure 5b).

\section{TC concentrations vary with tissue and are inversely correlated with viral load}

As the persistent viral replication in secondary lymphoid tissues did not seem to be related to infection of long-lived cells such as macrophages, we then hypothesized that it could be linked to poor antiviral activity. These could be due to either a poor diffusion of drugs in the tissue, active efflux from target cells or reduced nucleoside reverse transcriptase inhibitor (NRTI) phosphorylation by endocellular kinases. Drug pharmacokinetics (PK) can differ between species; however, we have previously shown [11] that $3 \mathrm{TC}$ in macaques treated with the same AZT/3TC/IDV combination displays very similar PK to humans. Thus, we first focused our measurements on the concentration of $3 \mathrm{TC}$ in different tissues of macaques treated with HAART between days 14 and 28 pi. Consistent with high impact of HAART on SIV replication in the gut, we found the highest 3TC concentration in the digestive tract ( $\mathrm{G}$ mean $2 \mathrm{nM} / 10^{6}$ cell equivalents (eq) in colon). The concentration in the spleen was about 100 times lower ( $\mathrm{G}$ mean: $0.017 \mathrm{nM} / 10^{6}$ cell eq), and the concentration in the peripheral $\mathrm{LN}$ was more than 300 times lower, than in colon (G mean: $0.006 \mathrm{nM} / 10^{6}$ cell eq) (Figure 6a). Tissue cell concentrations of 3TC$\mathrm{TP}$, the active form of the drug, varied in the same way (Figure 6b); and transformation rates - calculated by $3 \mathrm{TC}-\mathrm{TP}$ concentration/3TC concentration - were similar for each tissue tested ( $G$ means were 19.4 in PBMC, 26.2 in spleen and 25.7 in peripheral LN), indicating that efflux and phosphorylation of $3 \mathrm{TC}$ were not the limiting factors of antiviral activity in the 
(a) Plasma viral load

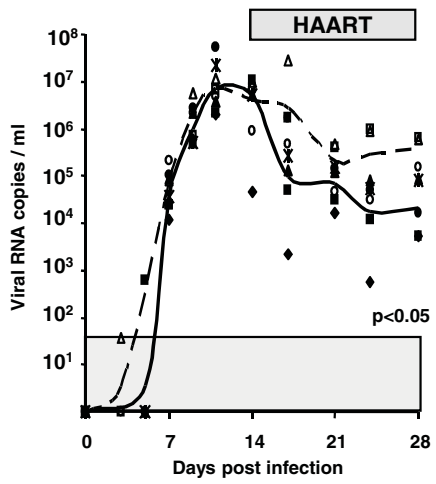

(d) Tissue 2LTR SIV-DNA

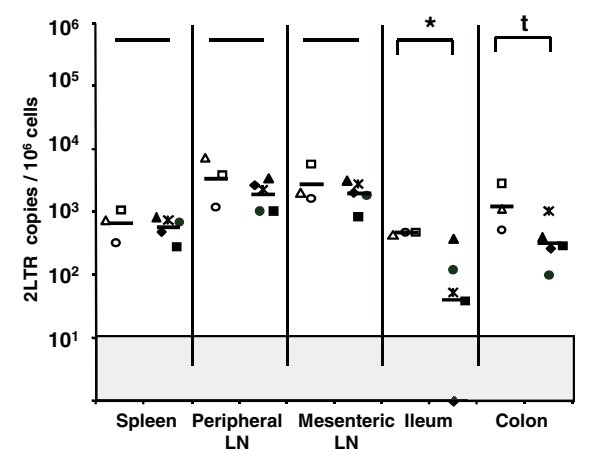

(b) Total viral DNA in PBMCs

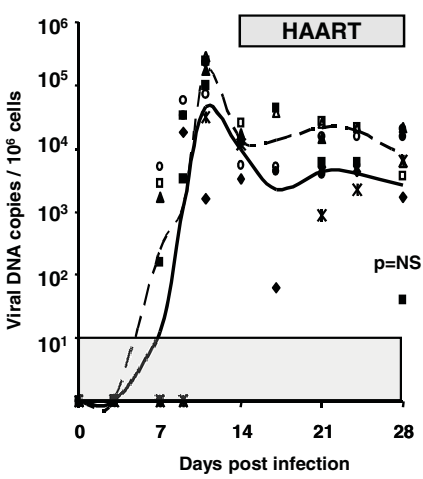

Days post infection (c) Tissue total SIV-DNA

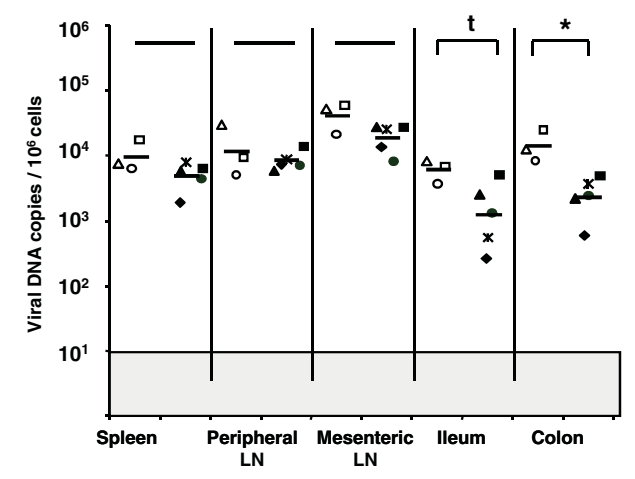

(e) Tissue SIV-RNA

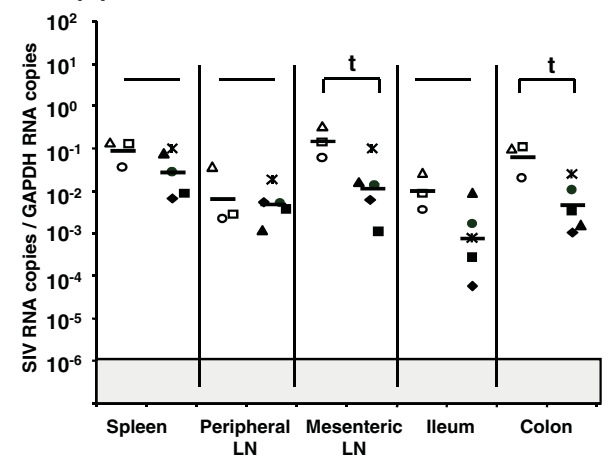

Figure 4 Viral dynamics in SIV-infected macaques receiving a short-term HAART just after the viremia peak. Among 8 animals infected since 14 days, 5 animals received the AZT/3TC/IDV combination (HAART d14-d28: black symbol) for 14 days whereas 3 animals received a placebo (placebo d28: open symbol) for the same period. All the animals were killed the end of treatment (28 days pi). HAART initiated at 14 days pi conducted to a significant reduction of PVL (a) but a non significant decrease of CVL (b). Viral dissemination (c) and replication (d,e) were reduced at different levels depending on the tissue considered: in the gut, the decrease was significant, whereas in spleen and peripheral LN, the viral dissemination and replication were almost maintained. *: indicated a significant difference $(p<0.05)$ and $t$ a trend $(0.05<p<0.06)$ using a MannWhitney test. LN: Iymph node, G mean: geometric mean. The grey area indicates the quantitative threshold of our qRT-PCR and qPCR assays.

different tissues. Interestingly, SIV-DNA level as indicator of residual viral load in tissues was inversely correlated $(\mathrm{p}<0.01)$ with $3 \mathrm{TC}$ local concentration (Figure 6c). Even though the correlation did not reach statistical significance $(\mathrm{p}=0,086)$, SIV-RNA level as indicator of residual viral replication also seemed to be inversely associated with 3TC local concentration (Figure 6d). We also investigated the concentrations of AZT and IDV in the same tissues. For AZT we found concentrations below the quantification threshold in almost all tissues explored (peripheral LN, spleen and colon); this may be due to the short half-life of AZT (data not shown). For IDV we found the same trend of diffusion as for 3TC with much higher concentrations in the colon (G mean: $102 \mathrm{pMol} / 10^{6}$ cell eq) than in the spleen ( $G$ mean: 0,094 pMol/ $10^{6}$ cell eq, $\mathrm{p}<0.05$ ). These results suggest that higher levels of residual viral replication in peripheral $\mathrm{LN}$ and spleen result, at least partially, from the low diffusion of antiviral drugs in these tissues.

\section{Discussion}

We showed that a short term HAART can reduce viral dissemination and replication in all tissues when initiated very early after intravenous inoculation of SIVmac251, before the viremia peak. In animals treated just after the initial viremia peak or during early chronic infection, we observed significant differences in HAART efficacy depending on the tissue considered. Maximum inhibition occurred in the digestive tract of macaques. These results are in accordance with those described in humans showing a rapid and large decrease of viral replication in GALT after successful HAART [12-15]. Although the GALT is considered today as the major site of HIV replication, there are no data about local diffusion of antiretroviral drugs in these tissues. The dosages of 3TC and IDV we performed demonstrate, for the first time, that two commonly used antiretrovirals can diffuse very efficiently in the digestive tract, thus probably explaining the high treatment efficacy observed in this tissue. As we had recently shown [3], in the same 


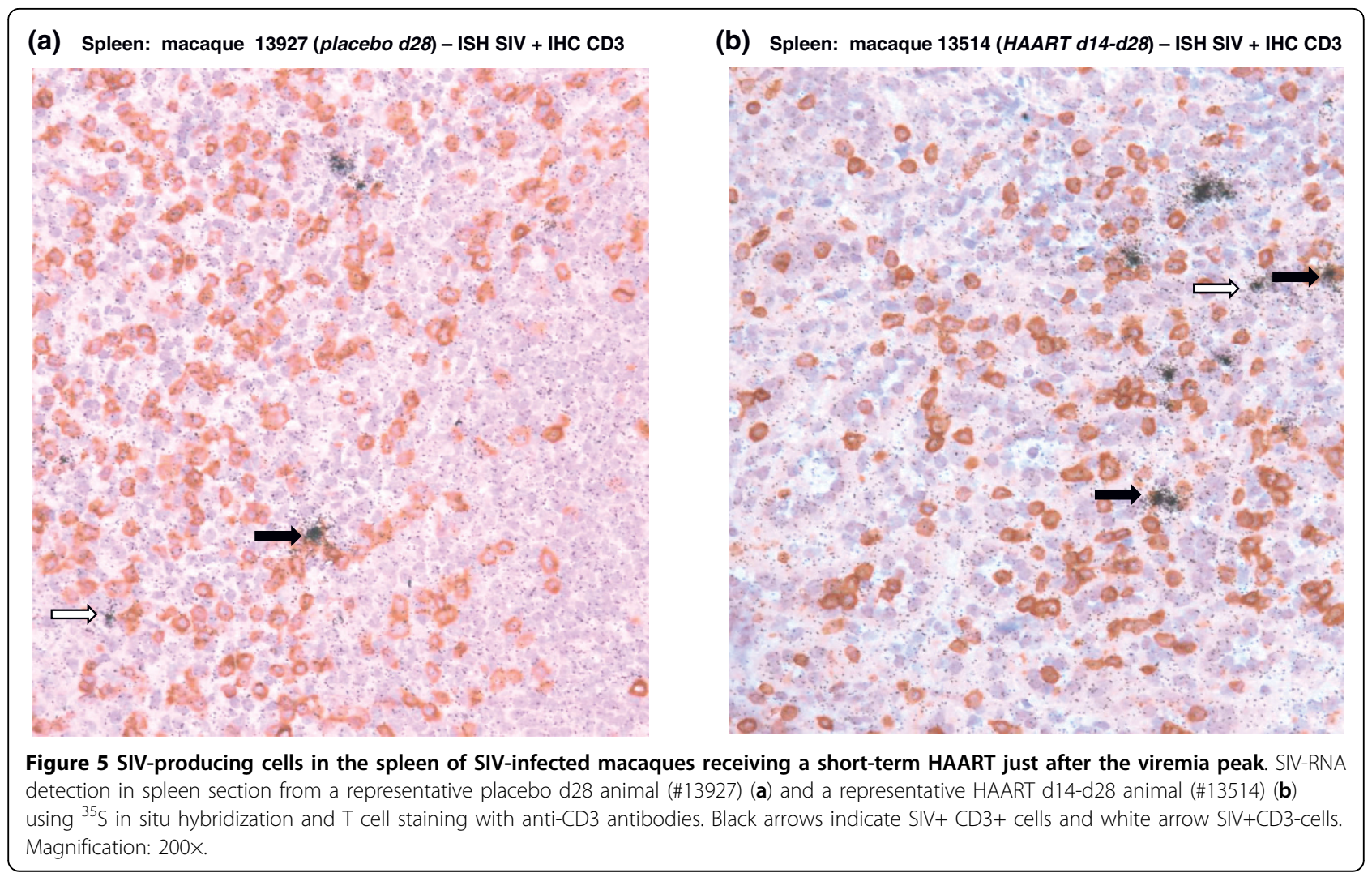

SIV macaque model, the plasma viral load mainly reflects the viral replication in the digestive tract. We could therefore suppose that the rapid decrease in plasma viral load observed after HAART initiation is mainly due to the control of viral replication in the gut.

Despite a strong effect in the GALT, currently used antiretroviral combinations are not sufficient to eradicate the virus. We therefore assume that residual replication in pharmacological sanctuaries and/or viral reservoirs could provide an explanation to the incomplete success of therapy. In patients treated with suboptimal regimens, like the use of only two NRTI, no significant changes were observed in viral replication in LN or tonsils, even after control of PVL [16-19]. Adding a protease inhibitor (PI) increases the efficiency of treatment without achieving a full control of replication even in infected patients with long term HAART $[10,17,20,21]$.

Our results confirm in the SIV-infected macaque model that HAART has limited impact on viral replication in secondary lymphoid tissues in spite of efficient control of PVL or replication in the gut. Contrary to Solas et al., who did not find any relationship between PI levels and HIV RNA levels in the tissues [22], the 3TC dosages we performed showed for the first time that low antiretroviral efficacy in spleen and peripheral lymph nodes could be related to poor drug diffusion in these organs, therefore favouring residual replication and viral persistence.

Corroborating the data from Kinman et al. [23], who showed very low diffusion of IDV in the lymph node of macaque after oral administration, the very low level of IDV measured in the spleen and peripheral lymph nodes of treated macaques confirm that secondary lymphoid tissues could act as real pharmacological sanctuaries.

Although one of the major limitations of our study is that drugs have been administered during a short period (14 to 28 days), several studies in humans indicate that even after several years of HAART, viral mRNA is still produced in peripheral lymph nodes. This confirms that the poor drug diffusion we observed in lymph node and spleen could provide a simple explanation to the absence of virus eradication. As suggested by Stellbrink [24], this residual replication in lymphoid tissues could also permanently seed the latent reservoir.

In the central nervous system (CNS) and the testis, the low levels of antiretroviral can be explained by poor diffusion across the blood-brain or blood-testicular barriers because of drugs efflux by $A B C$ transporter $[22,25,26]$. In the peripheral lymph node mononuclear cells, we previously demonstrated a higher level of P-gp mRNA expression than in PBMC [27]. However, we did 
(a) 3TC tissue concentrations

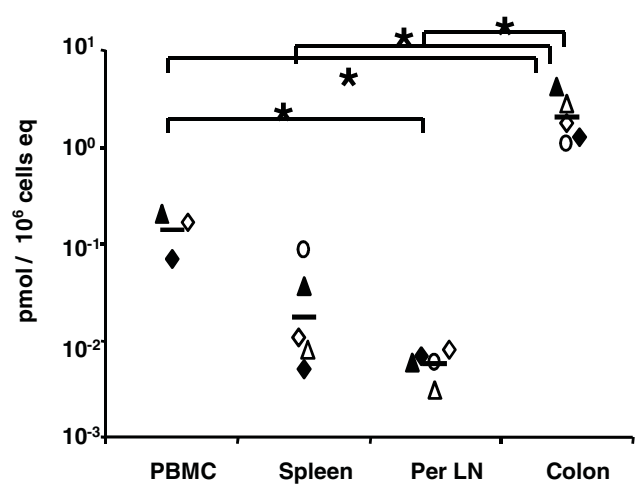

(b) 3TC-TP tissue concentrations

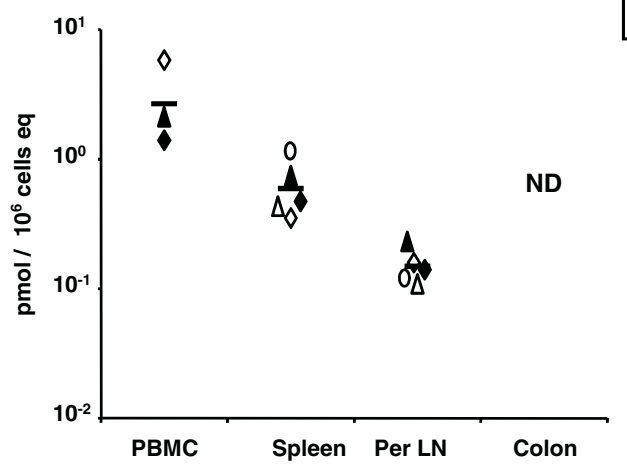

(c) Correlation between 3TC concentration and tissue residual viral load (DNA)

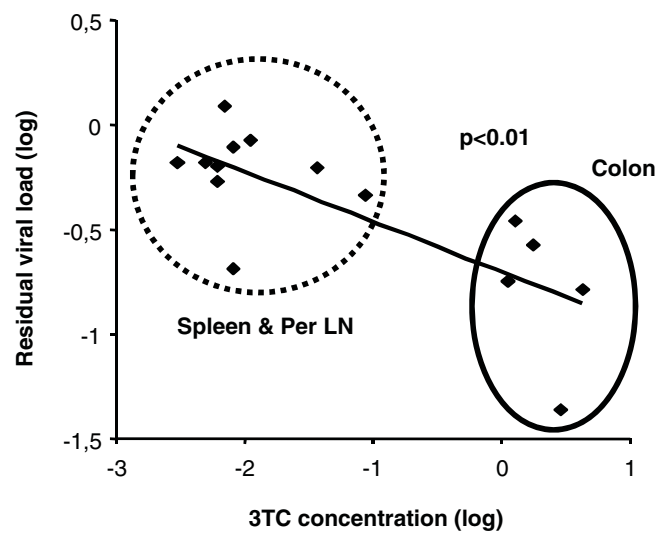

(d) Correlation between $3 \mathrm{TC}$ concentration and tissue residual viral replication (RNA)

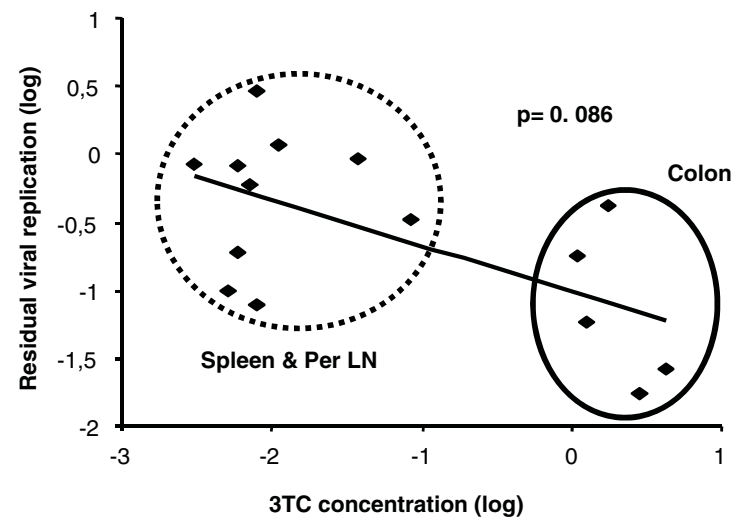

Figure 6 3TC levels in tissues of SIV-infected macaques receiving a short-term HAART just after the viremia peak. 3TC and 3TC-TP were measured in the tissues of macaque receiving the AZT/3TC/IDV combination between 14 and 28 days pi (HAART d14-d28). 3TC concentration was high in the colon, 100 times lower in the spleen and 300 times inferior in peripheral LN (a). 3TC-TP showed the same trend in distribution (b). Correlation between 3TC concentration and residual viral DNA (c) and RNA (d) in the lymphoid tissues showed an inverse relationship between 3TC concentration and the residual viral load $(\mathbf{c})$. *: indicated a significant difference $(p<0.05)$ using a Mann-Whitney test. G mean: Geometric mean, Per LN: peripheral lymph node.

not observe here any differences in the ratios of 3TC and 3TC-TP between the different tissues, indicating that efflux from the cell or kinases activities are not the limiting factors. It is therefore unlikely that P-gp activity is involved in the poor diffusion of antiretroviral we observed in secondary lymphoid tissues.

We also demonstrated that pharmokinetics and pharmacodynamic parameters are important to consider not only in the treatment of infected patients but also in preventive approaches of HIV transmission like post-exposure prophylaxis. After intravenous inoculation of SIVmac251, infection could not be prevented even if AZT/3TC/IDV combination was initiated within a few hours, confirming our previous results
$[9,28]$. Recently [11] we have shown that the same regimen prevents vaginal transmission of the same virus, probably because of initial viral compartmentalization and low dissemination [29] in association with good diffusion of NRTI in the female genital tract [30]. Our results thus demonstrate the need to improve antiretroviral biodistribution for better efficacy and limitation of the pharmacological sanctuaries that allow residual viral replication.

\section{Conclusions}

When initiated before the peak of viremia, a short-term antiretroviral treatment can impact viral dissemination and replication in almost all tissues. In this case, the 
treatment is more effective when initiated earlier. If the identical treatment is started after the peak of viremia, or during chronic infection, the effect of short-term HAART seems to vary according to the tissue considered. In the gut, where antiretroviral drugs diffuse easily, the viral burden decreases rapidly; whereas in secondary lymphoid tissues, poor diffusion of the antiviral drug could explain the weak effect of treatment on the tissue viral load.

\section{Methods}

\section{Animals, infections, treatment and tissue collection}

We studied 33 young adult male cynomolgus macaques (Macaca fascicularis), each weighing between 2.7 and $4.5 \mathrm{~kg}$. Studies were conducted in accordance with European guidelines for animal care and all experiments were approved by the ethics committee for animal experimentation "Ile de France Sud" (Paris, France). All macaques were inoculated intravenously with 50 AID $_{50}$ of pathogenic SIVmac251 and divided into nine groups.

Six animals were treated with AZT $(4.5 \mathrm{mg} / \mathrm{kg})$ and 3 TC $(2.5 \mathrm{mg} / \mathrm{kg})$ subcutaneously twice daily and indinavir $(60 \mathrm{mg} / \mathrm{kg})$, orally, twice daily. The treatment was initiated after viral set point (day $150 \mathrm{pi}$ ) and the animals were killed after 14 days (chronic HAART $14 \mathrm{~d}$ group) and 28 days (chronic HAART 28 d group) of treatment. In parallel, 3 untreated animals were also killed at 150 days pi (chronic untreated).

Four other animals received the AZT/3TC/IDV combination as early as $4 \mathrm{~h}$ post-infection and continued until day 14 when the animals were killed (HAART 4 h-d14 group). Four animals receiving a placebo in the same conditions were also killed at 14 days pi (placebo d14).

A group of four animals received the same HAART between days 7 and 21 pi (HAART d7-d21 group), then the animals were killed on day 21 pi. Four animals receiving a placebo in the same conditions were killed at 21 days pi (placebo $\mathrm{d} 21$ ).

In last group, 5 animals received the HAART treatment between day 14 and day 28 pi and were killed on day 28 (HAART d14-d28 group). Three animals receiving a placebo in the same conditions were killed at the same time (placebo d28).

Immediately after killing the animals, tissue samples from the spleen, peripheral lymph nodes (inguinal or axillary) mesenteric lymph nodes, ileum and colon were collected in quadruplicate and stored at $-80^{\circ} \mathrm{C}$. In order to reduce the heterogeneous presence of lymphoid tissue in the gut, we collected and processed large samples for ileum and colon (250 to $400 \mathrm{mg}$ ).

\section{Virological measurements in the blood}

Plasma and cell-associated viral loads were determined as previously described $[9,31]$.

\section{Virological measurements in the tissues}

RNA and DNA extraction as well as quantification of total SIV DNA, SIV 2 LTR circles and SIV RNA in tissue were performed as previously described [3].

\section{In situ hybridisation}

SIV gag in situ hybridization combined with immunohistochemistry for $\mathrm{T}$ cell markers was performed as previously described [32]. The specificity of the hybridization signal was systematically checked by hybridizing sense probes on successive sections. Image acquisition and analysis were performed on a Nikon i90 photomicroscope using NIS-elements software.

\section{Determination of antiretroviral concentration in tissues} 3TC, 3TC-TP, AZT and IDV were assayed by liquid chromatography coupled with tandem mass spectrometry (LC-MS/MS) or a modification of these methods, as previously described [33-35].

\section{Statistical analysis}

Statistical analyses were carried out using Stat View software (SAS institute Inc, Cary, North Carolina, USA). Plasma and cell-associated viral load as well as SIV-RNA, total SIV-DNA and 2LTR SIV-DNA were compared in placebo and HAART-treated macaques using a nonparametric Mann-Whitney test. Differences in 3TC and IDV concentration in lymphoid tissues were assessed by the same test. The correlation between 3TC concentration and residual viral replication/load in tissue, were evaluated using a nonparametric Spearman correlation test.

\section{Acknowledgements}

We greatly thank Patricia Brochard and Benoit Delache for their very efficient technical contribution. We thank Christophe Joubert and the technical staff of the CEA for animal care. We also thank Gaëlle Bourry for critical reading of the manuscript. We thank the Glaxo-Smith-Kline laboratories for helpful discussion and providing antiviral drugs.

\section{Author details}

${ }^{1}$ CEA, Division of Immuno-Virology, DSV/iMETI, Fontenay-aux-Roses, France. ${ }^{2}$ Assistance Publique-Hôpitaux de Paris, Hôpital Lariboisière, 2 rue Ambroise Paré, 75010 Paris, France. ${ }^{3}$ CEA, Service de Pharmacologie et d'Immunoanalyse, DSV/iBiTecS, CEA/Saclay, 91191Gif-sur-Yvette, France. ${ }^{4}$ Université Paris-Sud 11, UMR E01, Orsay, France. ${ }^{5}$ Inserm U625, Rennes, France.

\section{Authors' contributions}

RLG, OB and PR conceived and designed the experiments; $O B, P S, A M, C R$, LDG, RLG and PR performed the experiments; OB, PS, AM, CR, NDB, LDG, HB, $P R$ and RLG analyzed the data; HB contributed reagents/materials/analysis tools; OB, RLG, PS, PR and AM wrote the paper. All authors read and approved the final manuscript.

\section{Competing interests}

The authors declare that they have no competing interests.

Received: 5 May 2010 Accepted: 26 September 2010 Published: 26 September 2010 


\section{References}

1. Mattapallil JJ, Douek DC, Hill B, Nishimura Y, Martin M, Roederer M: Massive infection and loss of memory CD4+ T cells in multiple tissues during acute SIV infection. Nature 2005, 434:1093-1097.

2. Li Q, Duan L, Estes JD, Ma ZM, Rourke T, Wang Y, Reilly C, Carlis J, Miller CJ, Haase AT: Peak SIV replication in resting memory CD4+ T cells depletes gut lamina propria CD4+ T cells. Nature 2005, 434:1148-1152.

3. Mannioui A, Bourry O, Sellier P, Delache B, Brochard P, Andrieu T, Vaslin B, Karlsson I, Roques P, Le Grand R: Dynamics of viral replication in blood and lymphoid tissues during SIVmac251 infection of macaques. Retrovirology 2009, 6:106.

4. Tsai CC, Follis KE, Sabo A, Beck TW, Grant RF, Bischofberger N, Benveniste RE, Black R: Prevention of SIV infection in macaques by (R)-9(2-phosphonylmethoxypropyl)adenine. Science 1995, 270:1197-1199.

5. Ambrose Z, Kewalramani VN, Bieniasz PD, Hatziioannou T: HIV/AIDS: in search of an animal model. Trends Biotechnol 2007, 25:333-337.

6. Sharkey ME, Teo I, Greenough T, Sharova N, Luzuriaga K, Sullivan JL, Bucy RP, Kostrikis LG, Haase A, Veryard C, Davaro RE, Cheeseman SH, Daly JS, Bova C, Ellison RT, Mady B, Lai KK, Moyle G, Nelson M, Gazzard B, Shaunak S, Stevenson M: Persistence of episomal HIV-1 infection intermediates in patients on highly active anti-retroviral therapy. Nat Med 2000, 6:76-81.

7. Gulick RM, Mellors JW, Havlir D, Eron JJ, Gonzalez C, McMahon D, Richman DD, Valentine FT, Jonas L, Meibohm A, Emini EA, Chodakewitz JA: Treatment with indinavir, zidovudine, and lamivudine in adults with human immunodeficiency virus infection and prior antiretroviral therapy. N Engl J Med 1997, 337:734-739.

8. Haase AT: Perils at mucosal front lines for HIV and SIV and their hosts. Nature Reviews Immunology 2005, 5:783-792.

9. Benlhassan-Chahour K, Penit C, Dioszeghy $V$, Vasseur $F$, Janvier $G$, Riviere $Y$, Dereuddre-Bosquet N, Dormont D, Le Grand R, Vaslin B: Kinetics of lymphocyte proliferation during primary immune response in macaques infected with pathogenic simian immunodeficiency virus SIVmac251: preliminary report of the effect of early antiviral therapy. J Virol 2003 77:12479-12493.

10. Cavert W, Notermans DW, Staskus K, Wietgrefe SW, Zupancic M, Gebhard K, Henry K, Zhang ZQ, Mills R, McDade H, Schuwirth CM, Goudsmit J, Danner SA, Haase AT: Kinetics of response in lymphoid tissues to antiretroviral therapy of HIV-1 infection. Science 1997, 276:960-964.

11. Bourry O, Brochard P, Souquiere S, Makuwa M, Calvo J, DereudreBosquet N, Martinon F, Benech H, Kazanji M, Le Grand R: Prevention of vaginal simian immunodeficiency virus transmission in macaques by postexposure prophylaxis with zidovudine, lamivudine and indinavir. AIDS 2009, 23:447-454.

12. Talal AH, Monard S, Vesanen $M$, Zheng Z, Hurley A, Cao Y, Fang F, Smiley L, Johnson J, Kost R, Markowitz MH: Virologic and immunologic effect of antiretroviral therapy on HIV-1 in gut-associated lymphoid tissue. $J$ Acquir Immune Defic Syndr 2001, 26:1-7.

13. Kotler DP, Shimada T, Snow G, Winson G, Chen W, Zhao M, Inada Y, Clayton F: Effect of combination antiretroviral therapy upon rectal mucosal HIV RNA burden and mononuclear cell apoptosis. Aids 1998, 12:597-604.

14. Anton PA, Mitsuyasu RT, Deeks SG, Scadden DT, Wagner B, Huang C, Macken C, Richman DD, Christopherson C, Borellini F, Lazar R, Hege KM: Multiple measures of HIV burden in blood and tissue are correlated with each other but not with clinical parameters in aviremic subjects. Aids 2003, 17:53-63.

15. Poles MA, Boscardin WJ, Elliott J, Taing P, Fuerst MM, McGowan I, Brown S, Anton PA: Lack of decay of HIV-1 in gut-associated lymphoid tissue reservoirs in maximally suppressed individuals. J Acquir Immune Defic Syndr 2006, 43:65-68.

16. Haase AT, Henry K, Zupancic M, Sedgewick G, Faust RA, Melroe $H$, Cavert W, Gebhard K, Staskus K, Zhang ZQ, Dailey PJ, Balfour HH Jr, Erice A, Perelson AS: Quantitative image analysis of HIV-1 infection in lymphoid tissue. Science 1996, 274:985-989.

17. Lafeuillade A, Chollet L, Hittinger G, Profizi N, Costes O, Poggi C: Residual human immunodeficiency virus type 1 RNA in lymphoid tissue of patients with sustained plasma RNA of $<200$ copies $/ \mathrm{mL}$. J Infect Dis 1998, 177:235-238.

18. Ruiz L, van Lunzen J, Arno A, Stellbrink HJ, Schneider C, Rull M, Castellà E, Ojanguren I, Richman DD, Clotet B, Tenner-Racz K, Racz P: Protease inhibitor-containing regimens compared with nucleoside analogues alone in the suppression of persistent HIV-1 replication in lymphoid tissue. Aids 1999, 13:F1-8.

19. Martínez E, Arnedo M, Giner V, Gil C, Caballero M, Alós L, García F Holtzer C, Mallolas J, Miró JM, Pumarola T, Gatell JM: Lymphoid tissue viral burden and duration of viral suppression in plasma. Aids 2001, 15:1477-1482.

20. Wong JK, Gunthard HF, Havlir DV, Zhang ZQ, Haase AT, Ignacio CC, Kwok S, Emini E, Richman DD: Reduction of HIV-1 in blood and lymph nodes following potent antiretroviral therapy and the virologic correlates of treatment failure. Proc Natl Acad Sci USA 1997, 94:12574-12579.

21. Notermans DW, Jurriaans S, de Wolf F, Foudraine NA, de Jong JJ, Cavert W, Schuwirth CM, Kauffmann RH, Meenhorst PL, McDade H, Goodwin C, Leonard JM, Goudsmit J, Danner SA: Decrease of HIV-1 RNA levels in lymphoid tissue and peripheral blood during treatment with ritonavir, lamivudine and zidovudine. Ritonavir/3TC/ZDV Study Group. Aids 1998, 12:167-173.

22. Solas C, Lafeuillade A, Halfon P, Chadapaud S, Hittinger G, Lacarelle B: Discrepancies between protease inhibitor concentrations and viral load in reservoirs and sanctuary sites in human immunodeficiency virusinfected patients. Antimicrob Agents Chemother 2003, 47:238-243.

23. Kinman L, Brodie SJ, Tsai CC, Bui T, Larsen K, Schmidt A, Anderson D, Morton WR, Hu SL, Ho RJ: Lipid-drug association enhanced HIV-1 protease inhibitor indinavir localization in lymphoid tissues and viral load reduction: a proof of concept study in HIV-2287-infected macaques. J Acquir Immune Defic Syndr 2003, 34:387-397.

24. Stellbrink HJ, van Lunzen J, Westby M, O'Sullivan E, Schneider C, Adam A Weitner L, Kuhlmann B, Hoffmann C, Fenske S, Aries PS, Degen O, Eggers C, Petersen H, Haag F, Horst HA, Dalhoff K, Möcklinghoff C, Cammack N, Tenner-Racz K, Racz P: Effects of interleukin-2 plus highly active antiretroviral therapy on HIV-1 replication and proviral DNA (COSMIC trial). Aids 2002, 16:1479-1487.

25. Wong SL, Van Belle K, Sawchuk RJ: Distributional transport kinetics of zidovudine between plasma and brain extracellular fluid/cerebrospinal fluid in the rabbit: investigation of the inhibitory effect of probenecid utilizing microdialysis. J Pharmacol Exp Ther 1993, 264:899-909.

26. Hamidi M: Role of P-glycoprotein in tissue uptake of indinavir in rat. Life Sci 2006, 79:991-998.

27. Jorajuria S, Clayette P, Dereuddre-Bosquet N, Benlhassan-Chahour K, Thiebot H, Vaslin B, Le Grand R, Dormont D: The expression of Pglycoprotein and cellular kinases is modulated at the transcriptional level by infection and highly active antiretroviral therapy in a primate model of AIDS. AIDS Res Hum Retroviruses 2003, 19:307-311.

28. Le Grand R, Vaslin B, Larghero J, Neidez O, Thiebot H, Sellier P, Clayette P, Dereuddre-Bosquet N, Dormont D: Post-exposure prophylaxis with highly active antiretroviral therapy could not protect macaques from infection with SIV/HIV chimera. Aids 2000, 14:1864-1866.

29. Pope M, Haase AT: Transmission, acute HIV-1 infection and the quest for strategies to prevent infection. Nat Med 2003, 9:847-852.

30. Dumond JB, Yeh RF, Patterson KB, Corbett AH, Jung BH, Rezk NL, Bridges AS, Stewart PW, Cohen MS, Kashuba AD: Antiretroviral drug exposure in the female genital tract: implications for oral pre-and postexposure prophylaxis. Aids 2007, 21:1899-1907.

31. Puaux AL, Marsac D, Prost S, Singh MK, Earl P, Moss B, Le Grand R, Riviere $Y$, Michel ML: Efficient priming of simian/human immunodeficiency virus (SHIV)-specific T-cell responses with DNA encoding hybrid SHIV/hepatitis B surface antigen particles. Vaccine 2004, 22:3535-3545.

32. Roulet V, Satie AP, Ruffault A, Le Tortorec A, Denis H, Guist'hau O, Patard JJ, Rioux-Leclerq N, Gicquel J, Jegou B, Dejucq-Rainsford N: Susceptibility of human testis to human immunodeficiency virus-1 infection in situ and in vitro. Am J Pathol 2006, 169:2094-2103.

33. Compain S, Durand-Gasselin L, Grassi J, Benech H: Improved method to quantify intracellular zidovudine mono-and triphosphate in peripheral blood mononuclear cells by liquid chromatography-tandem mass spectrometry. J Mass Spectrom 2007, 42:389-404.

34. Compain S, Schlemmer D, Levi M, Pruvost A, Goujard C, Grassi J, Benech H: Development and validation of a liquid chromatographic/tandem mass spectrometric assay for the quantitation of nucleoside HIV reverse transcriptase inhibitors in biological matrices. J Mass Spectrom 2005 40:9-18. 
35. Becher F, Pruvost A, Goujard C, Guerreiro C, Delfraissy JF, Grassi J, Benech H: Improved method for the simultaneous determination of d4T, 3TC and ddl intracellular phosphorylated anabolites in human peripheral-blood mononuclear cells using high-performance liquid chromatography/ tandem mass spectrometry. Rapid Commun Mass Spectrom 2002, 16:555-565.

doi:10.1186/1742-4690-7-78

Cite this article as: Bourry et al:: Effect of a short-term HAART on SIV

load in macaque tissues is dependent on time of initiation and antiviral diffusion. Retrovirology 2010 7:78.

Submit your next manuscript to BioMed Central and take full advantage of:

- Convenient online submission

- Thorough peer review

- No space constraints or color figure charges

- Immediate publication on acceptance

- Inclusion in PubMed, CAS, Scopus and Google Scholar

- Research which is freely available for redistribution

Submit your manuscript at www.biomedcentral.com/submit
C Biomed Central 